\title{
Effect of calcitriol on the production of T-cell-derived cytokines in psoriasis
}

\author{
M.BARNA, ${ }^{*} \dagger+$ J.D.BOS, $\dagger$ M.L.KAPSENBERG* AND F.G.M.SNIJDEWINT*† \\ *Laboratory of Cell Biology and Histology, University of Amsterdam, Meibergdreef 15, 1105 AZ Amsterdam, the Netherlands \\ $\dagger$ Department of Dermatology, University of Amsterdam, Meibergdreef 9, 1105 AZ Amsterdam, the Netherlands \\ $\ddagger$ Department of Dermatology, Albert Szent-Györgyi Medical University, H-6701 Szeged, PO Box 480, Hungary \\ Accepted for publication 6 September 1996
}

Summary Although the use of vitamin D analogues in the treatment of psoriasis has been an important new development, the mechanisms of action of these drugs are not fully understood. Psoriasis results from hyperproliferation of keratinocytes, and various studies attribute a crucial role to the locally infiltrating $\mathrm{T}$ lymphocytes. In an attempt to add to the understanding of the mechanisms of calcitriol therapy, we determined the effect of this drug on T cells by studying its effect on proliferation and on the production of various cytokines by T-cell clones prepared from psoriatic skin after non-specific activation with the combination of phytohaemagglutinin (PHA) and phorbol myristate acetate (PMA). The addition of increasing doses $\left(10^{-9}-10^{-5} \mathrm{~mol} / \mathrm{l}\right)$ of calcitriol to these T cells resulted in a dose-dependent inhibition in lymphocyte proliferation and in production of the type 1 cytokines IFN$\gamma$ and IL-2, the type 2 cytokines IL- 4 and IL- 5 . The general cytokines TNF- $\alpha$ and GM-CSF were not significantly inhibited. These data suggest that calcitriol is involved in the treatment of psoriasis via inhibition of the expansion, and cytokine production, of skin-infiltrating T lymphocytes.

A major role of $1 \alpha, 25$-dihydroxyvitamin $\mathrm{D}_{3}\left(1,25(\mathrm{OH})_{2} \mathrm{D}_{3}\right.$ or calcitriol) is the regulation of calcium metabolism in humans. ${ }^{1,2}$ In addition, calcitriol affects the skin via its effect on keratinocytes. In vitro studies have shown the occurrence of high-affinity low-capacity receptors for this hormone in human keratinocytes. ${ }^{3}$ Incubation of human keratinocytes with calcitriol induced their morphological differentiation and resulted in an increased transglutaminase activity and a decreased proliferation in these cells. ${ }^{4}$ Furthermore, calcitriol modulates immune cells as substantiated by studies indicating the local production of calcitriol by macrophages ${ }^{5}$ and the demonstration of specific receptors for vitamin $\mathrm{D}_{3}$ in monocytes and activated lymphocytes. ${ }^{6}$

Authors examining the activity of calcitriol on human peripheral blood mononuclear cells ${ }^{7}$ have revealed that the compound is a potent inhibitor of phytohaemagglutinin (PHA)-stimulated lymphocyte proliferation. It was also found that the production of the type 1 cytokines interleukin-2 (IL-2) and interferon- $\gamma$ (IFN- $\gamma$ )

\footnotetext{
This paper was presented in part at the Annual Meeting of the European Society for Dermatological Research, Vienna, 24-27 September 1994. Correspondence: Magdolna Barna, Department of Dermatology, Albert Szent-Györgyi Medical University, H-6701 Szeged, PO Box 480, Hungary.
}

by lymphocytes was inhibited by calcitriol in a dosedependent fashion. ${ }^{8}$

Several groups have shown that calcitriol applied either systematically or locally is useful in the treatment of psoriasis. ${ }^{9,10}$ The exact mechanisms of action of calcitriol in psoriasis are not known, but inhibition of the production of cytokines produced by keratinocytes and lymphocytes may be crucial. ${ }^{11}$ One potential target is the population of skin-infiltrating $\mathrm{T}$ cells, because these cells seem to play a part in the pathogenesis of psoriasis. T cells are found to be infiltrated in psoriatic skin and cyclosporin A, which is a selective inhibitor of T-cell proliferation and cytokine production, reduces the severity of the disease. ${ }^{12}$

The way that $\mathrm{T}$ cells contribute to psoriasis is not exactly known. T cells can be functionally categorized as cells secreting predominantly the type 1 cytokines IL-2 and IFN- $\gamma$ (Th1 cells), cells predominantly producing type 2 cytokines IL- 4 , IL-5 and IL-10 (Th2 cells), and cells producing both type 1 and type 2 cytokines (Th0 cells), whereas all these cell types produce cytokines such as TNF- $\alpha$ and GM-CSF. Many of these cytokines are candidates to interact with epithelial cells. The current literature regarding the existence of a distinct cytokine pattern in lesional psoriatic skin is confusing. Some 
authors report a correlation between the development of a psoriatic lesion and the accumulation of type $1 \mathrm{~T}$ helper lymphocytes ${ }^{13,14}$ but, in other studies, including our previous study, the authors did not find an association with the Th1 or Th2 pattern. ${ }^{15,16}$

In the present study we, therefore, examined the effect of calcitriol on T cells in more detail, by analysing the effect on T-cell proliferation and the production of a broad panel of T-cell cytokines, including the type 1 cytokines IL- 2 and IFN- $\gamma$, the type 2 cytokines IL- 4 and IL-5, and the more generally produced cytokines TNF- $\alpha$ and GM-CSF. Previously, Muller et al. ${ }^{17}$ and Lemire et $a l .{ }^{18}$ reported on specific inhibition of proliferation and IL- 2 or IFN- $\gamma$ production of human T-cell lines/clones by calcitriol. We used, for this study, T-cell clones prepared from psoriatic lesions, allowing the analysis of the effect of calcitriol on the proliferation and cytokine production of psoriasis-associated T cells. The study demonstrates that calcitriol inhibits the proliferation and the production of the type 1 and type 2 cytokines of psoriatic T cells.

\section{Materials and methods}

T-cell clones, reagents and culture media

Lesional skin biopsy specimens $(n=2)$ were obtained from the forearm of six patients suffering from chronic plaque psoriasis. No local or systemic therapy had been given to the patients for 6 weeks before taking the biopsies.

The preparation of the T-cell clones used in this study has been described earlier. ${ }^{19}$ T-cell clones were maintained in Iscove's modified Dulbecco medium (IMDM) (GIBCO, Paisley, Scotland), supplemented with 10\% pooled complement-inactivated normal human serum (Central Laboratory Blood Transfusion Service, Amsterdam, The Netherlands), rIL-2 (20 U/ml) (Cetus Corp., Emeryville, California, U.S.A.) and gentamicin $(80 \mu \mathrm{g} / \mathrm{ml})$ and were restimulated every second week using phytohaemagglutinin (PHA), irradiated allo-peripheral blood mononuclear cells and JY cells as stimulants. When cells were stimulated for assaying cytokine production, human serum was replaced by $10 \%$ fetal calf serum (FCS) (HyClone Laboratories Inc., Logan, UT, U.S.A.) and the medium further supplemented with $35 \mu \mathrm{g} / \mathrm{ml}$ human transferrin (Behring-Werke, Magdeburg, Germany), 1.75 IE/ml human insulin (Actrapid, Novo Nordish A/S, Bagsvaerd, Denmark) and $3.5 \mu \mathrm{l} / \mathrm{l} \quad \beta$-mercaptoethanol (Merck, Munich, Germany). The Epstein-Barr virus-transformed human
B-cell line JY was maintained in IMDM containing 5\% FCS. All cultures were incubated at $37{ }^{\circ} \mathrm{C}$ in a humidified atmosphere containing $5 \% \mathrm{CO}_{2}$.

Calcitriol provided by Solvay Duphar BV (Weesp, The Netherlands) was dissolved in $96 \%$ ethanol to a stock concentration of $1 \times 10^{-3} \mathrm{~mol} / \mathrm{l}$ and stored at $-20^{\circ} \mathrm{C}$. The various concentrations $\left(10^{-9}-10^{-5} \mathrm{~mol} / \mathrm{l}\right)$ were obtained by diluting the stock solution in IMDM. A vehicle control was included in all experiments. The final ethanol concentration was $0 \cdot 0001 \%-1 \%$ in the culture medium.

The cell viability was measured by the XTT colorimetric assay (Boehringer Mannheim Biochemica, Germany, \#1465015).

\section{T-cell proliferation assay}

T-cell clones $\left(2 \times 10^{4} /\right.$ well $)$ were washed three times in Hanks' balanced salt solution (HBSS; GIBCO, Paisley, Scotland) $+2 \%$ FCS and stimulated with $1 \mu \mathrm{g} / \mathrm{ml}$ phytohaemagglutinin (PHA, Difco, Detroit, MI, U.S.A.) and $5 \mathrm{ng} / \mathrm{ml}$ phorbol myristate acetate (PMA, Sigma Chemical Co., St Louis, MO, U.S.A.) in the presence of $10^{-5}$ $10^{-9} \mathrm{~mol} / \mathrm{l}$ calcitriol in Costar 96-well flat-bottomed culture plates. Cells were cultured for $40 \mathrm{~h}$, the last $16 \mathrm{~h}$ in the presence of $0.3 \mu \mathrm{Ci} /$ well of $\left[{ }^{3} \mathrm{H}\right]$ thymidine (TdR, Radiochemical Centre, Amersham, U.K.). Incorporation of $\left[{ }^{3} \mathrm{H}\right] \mathrm{TdR}$ was determined by liquid scintillation spectroscopy and expressed as mean counts per minute (c.p.m.) of triplicate cultures.

\section{Assays for cytokine production}

Cytokine production assays were performed in 96-well flat-bottomed microtitre plates (Costar) 10 days after the last restimulation. $10^{5} \mathrm{~T}$ cells were stimulated with $1 \mu \mathrm{g} / \mathrm{ml}$ PHA and $5 \mathrm{ng} / \mathrm{ml}$ PMA together with $10^{-5}$ $10^{-9} \mathrm{~mol} / \mathrm{l}$ calcitriol in a volume of $200 \mu \mathrm{l}$ per well. Controls were supernatants of cells cultured in the medium alone. Cell-free supernatants were harvested after $24 \mathrm{~h}$, stored immediately at $-20{ }^{\circ} \mathrm{C}$, and thawed before testing. All experiments were performed twice in triplicate. The measurement of IL-4 and IFN- $\gamma$ levels in the supernatants was performed with specific solidphase sandwich ELISA systems, as described elsewhere. ${ }^{20,21}$ Measurements of GM-CSF in supernatants were performed with sandwich ELISA composed of monoclonal antibody from Pharmingen Diagnostics BV, Uithoorn, The Netherlands 18581D. The levels of IL-2, IL- 5 and TNF- $\alpha$ in the supernatants were determined by using the IL-2-dependent murine CTLL-2 cell 


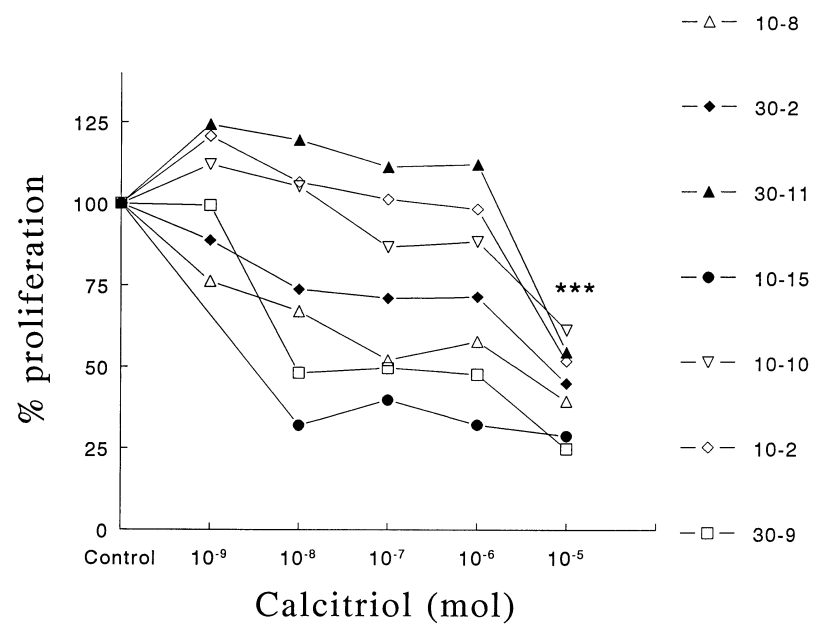

Figure 1. Proliferation by seven lesional skin T-cell clones following PHA $(1 \mu \mathrm{g} / \mathrm{ml})$ and PMA $(5 \mathrm{ng} / \mathrm{ml})$ stimulation for $40 \mathrm{~h}$ in the presence or absence of calcitriol. Each symbol and the consecutive numbers represent a distinct T-cell clone. Results are expressed as per cent of control values. Calcitriol dose-dependently inhibits proliferation (ANOVA, $P=0 \cdot 0004$ ). ${ }^{* * *} P<0 \cdot 001$, multiple comparisons test, control vs. dose calcitriol.

line, ${ }^{22}$ the IL-5-dependent cell line $\mathrm{B} 13^{23}$ and the cell killing of the L929 fibroblast cell line in the presence of TNF- $\alpha,{ }^{24}$ respectively. The tested agents, at the concentrations used, did not interfere with the proliferation of the CTLL-2, B13 or L929 cells.

\section{Statistical analysis}

Results of measurements were statistically analysed using one-way and repeated measures analysis of variance (ANOVA) and the Student-Newman-Keuls multiple comparisons test.

\section{Results}

To determine the effect of calcitriol on proliferation and cytokine production of T-cell clones, representative clones were stimulated with the combination of PHA and PMA in the presence of $10^{-9}-10^{-5} \mathrm{~mol} / \mathrm{l}$ calcitriol. In some experiments similar concentrations of hydrocortisone and cyclosporin A served as a control and both compounds caused dose-dependent inhibition of all tested cytokines (data not shown).

Calcitriol at the concentration of $10^{-8}-10^{-5} \mathrm{~mol} / \mathrm{l}$ dose-dependently inhibited the proliferation of the tested T-cell clones (Fig. 1) (ANOVA, $P=0 \cdot 0004$ ). The decrease in proliferation was not due to a decrease in cell survival, as the cell viability as measured by the XTT colorimetric assay was similar in all test conditions (data not shown).

As reported before, the cytokine profile of stimulated psoriatic T-cell clones varied considerably, with some clones that did not produce either type 1 or type 2 cytokines. ${ }^{16}$ However, in all cases when these cytokines were produced, calcitriol dose-dependently inhibited the production of the type 1 cytokines IL-2 (ANOVA, $P<0 \cdot 0001)$ and IFN- $\gamma($ ANOVA, $P=0 \cdot 0031)$ as well as the type 2 cytokines IL-4 (ANOVA, $P=0 \cdot 0268$ ) and IL5 (ANOVA, $P<0 \cdot 0001$ ) (Fig. 2). Calcitriol did not significantly inhibit the production of the non-Th1/ Th2-associated cytokines TNF- $\alpha$ (ANOVA, $P=0 \cdot 7498$ ) and GM-CSF (ANOVA, $P=0 \cdot 0692$ ) (Fig. 3).

\section{Discussion}

Since the discovery of receptors for calcitriol in human monocytes and activated, but not resting $\mathrm{T}$ lymphocytes, ${ }^{6,25}$ much attention has been focused on the participation of the vitamin $\mathrm{D}_{3}$-endocrine system in immunoregulatory processes. In our experiments, calcitriol was capable of suppressing lymphocyte proliferation. The maximum inhibition of lectin-induced lymphocyte proliferation was $70 \%$. From the work of Rigby et al. ${ }^{7}$ we know that specific receptors for vitamin $\mathrm{D}$ are not detectable in T lymphocytes until $24 \mathrm{~h}$ after lectin stimulation. The absence of an inhibitory effect on proliferation of some of the T-cell clones, therefore, may be explained by the lack of receptors for calcitriol in these cells at the onset of the experiment.

Our previous study showed that the skin-infiltrating lymphocytes do not show shifts towards either a Th1 or a Th2 cytokine production profile. ${ }^{16}$ Therefore we examined the effect of calcitriol on proliferation and the production of cytokines by Th0, Th1 and Th 2 cells. Cytokine production was inhibited by calcitriol in a dose-dependent fashion with an effect at concentrations as low as $10^{-9} \mathrm{~mol} / \mathrm{l}$ calcitriol in the culture medium. The physiological concentration of calcitriol in normal human serum is $10^{-10} \mathrm{~mol} / \mathrm{l}^{26}$ Calcitriol was not toxic for $\mathrm{T}$ cells in any concentration used, since XTT assay showed similar cell viability in all test conditions.

Several studies prompted that the effect of calcitriol on cytokine synthesis is receptor-mediated. The receptor is a specific nuclear receptor (vitamin D receptor), which is related to the steroid, thyroid and retinoic acid receptor superfamily. Vitamin D receptors are expressed not only by lymphocytes but by keratinocytes, monocytes and macrophages as well. The receptor complex interacts with DNA sequences regulating 
Interleukin-2

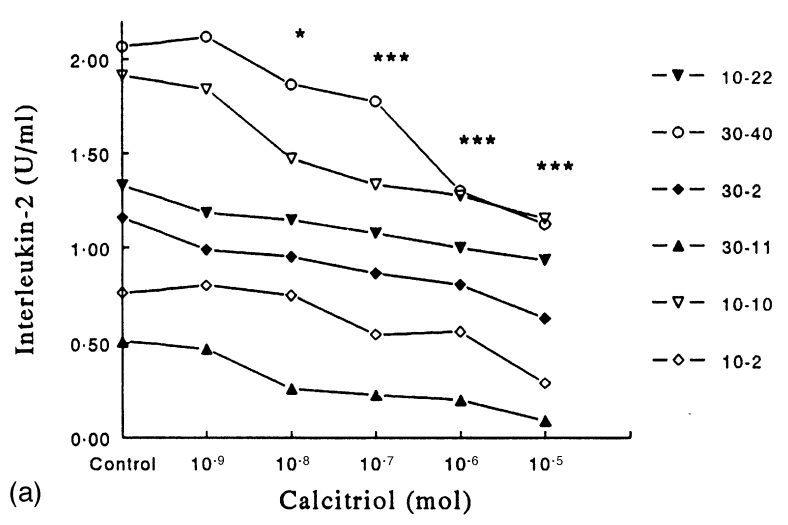

Interleukin-4

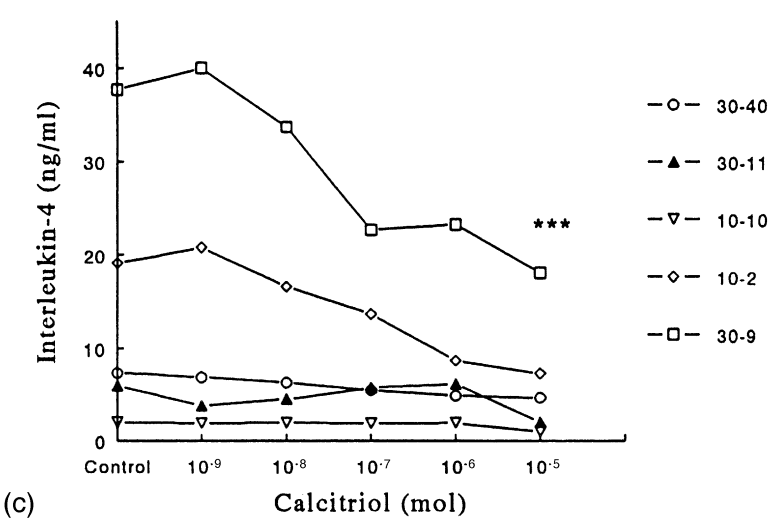

Interferon- $\gamma$

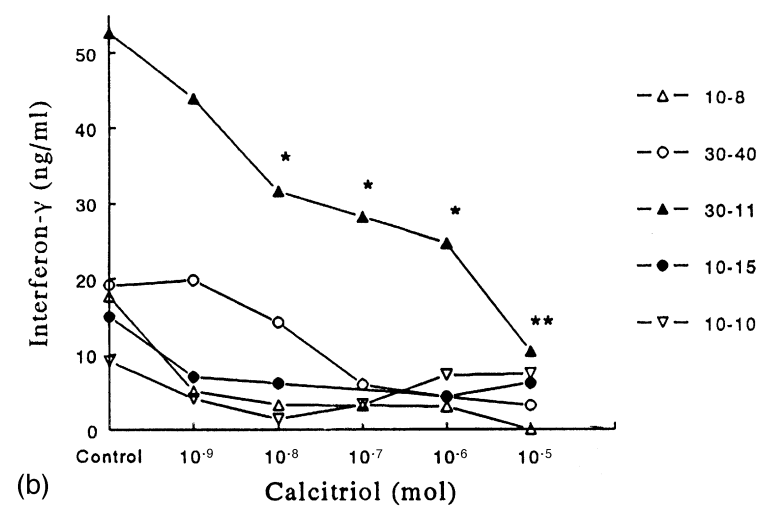

Interleukin-5

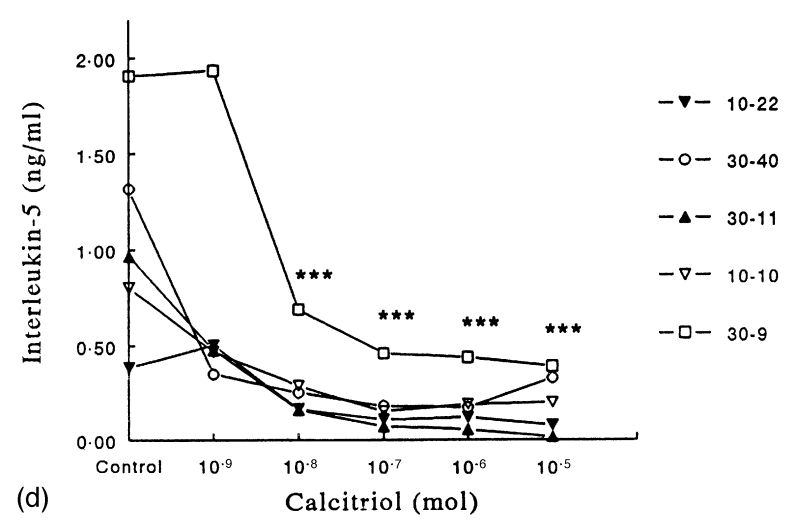

Figure 2. (a-d) Effect of calcitriol on T-cell derived cytokines following PHA $(1 \mu \mathrm{g} / \mathrm{ml})$ and PMA $(5 \mathrm{ng} / \mathrm{ml}) \mathrm{stimulation}$ for $24 \mathrm{~h}$ in the presence or absence of calcitriol. Calcitriol dose-dependently inhibits cytokine production (ANOVA IL-2, $P<0 \cdot 0001 ;$ IFN- $\gamma, P=0 \cdot 0031$; IL-4, $P=0 \cdot 0268 ;$ IL-5, $P<0 \cdot 0001)$. ${ }^{*} P<0 \cdot 05 ;{ }^{* *} P<0 \cdot 01 ;{ }^{* * *} P<0 \cdot 001$.

synthesis of mRNA involved in cell growth and differentiation. ${ }^{27}$ More than 400 vitamin $\mathrm{D}_{3}$ responsive genes have been reported recently. ${ }^{28}$

The study of Tsoukas et al. ${ }^{29}$ suggested that calcitriolmediated inhibition of lymphocyte proliferation and IL-2 synthesis was dependent on the presence of monocytes in cell cultures. Our experiments are inconsistent with such a requirement of accessory cells (B cells, monocytes) for calcitriol-mediated inhibition because they were performed with pure T-cell clones stimulated in the absence of accessory cells. Similar inhibition of cytokine production and proliferation was observed in peripheral blood lymphocytes and keratinocytes. ${ }^{3,30}$ Lemire et al. and Muller et al. found some selectivity in cytokine inhibition; in their systems calcitriol preferentially inhibited Th1-type cytokines. $^{17,18}$ The authors of these studies used different cloning procedures and lower calcitriol concentrations. The spectrum of cytokines they investigated was generally smaller and the studies had excluded IL-5 or the general cytokines TNF- $\alpha$ and GM-CSF. We cloned $\mathrm{T}$ cells directly from psoriatic lesions and by lectin stimulation we were able to detect type 1 and type 2 cytokines as well. In accordance with Baadsgaard, ${ }^{27}$ we could demonstrate direct inhibition of type 1 and type 2 cytokines by calcitriol.

The present study indicates that calcitriol controls immunological reactions by a generalized down-regulation 

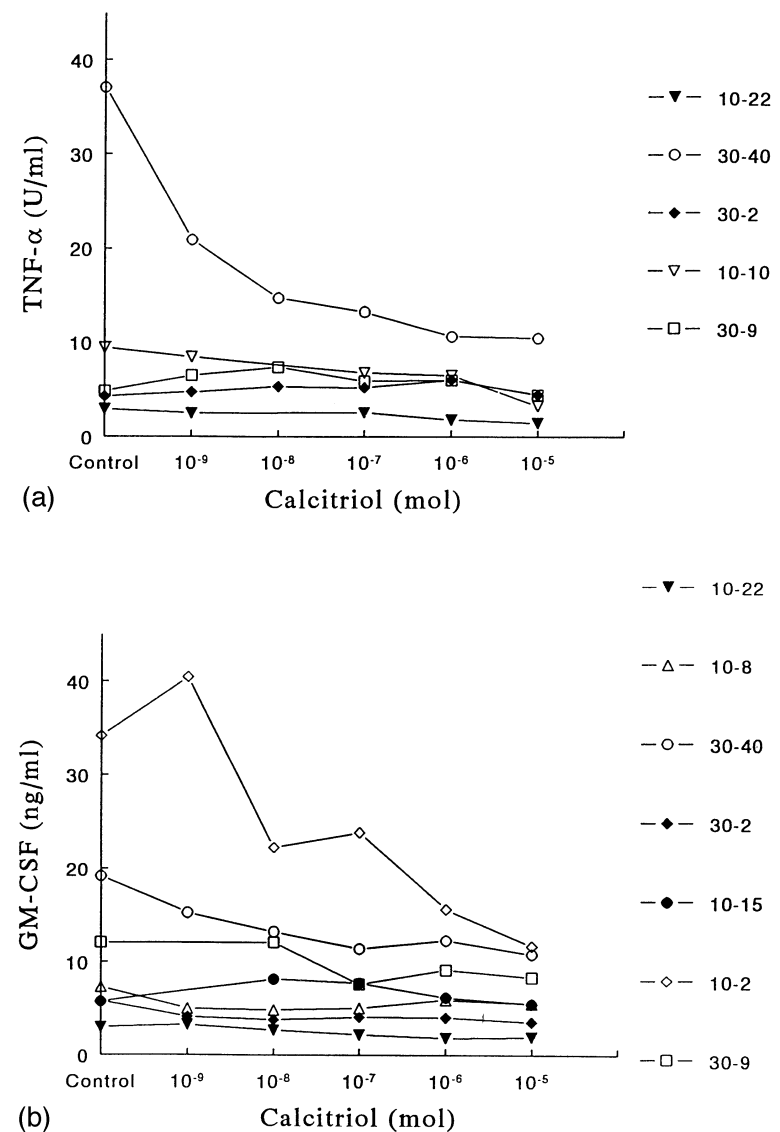

Figure 3. Effect of calcitriol on (a) TNF- $\alpha$ and (b) GM-CSF production following PHA $(1 \mu \mathrm{g} / \mathrm{ml})$ and PMA $(5 \mathrm{ng} / \mathrm{ml})$ stimulation; T cells were incubated for $24 \mathrm{~h}$ in the presence or absence of calcitriol. The inhibition of cytokines was not significant (ANOVA TNF- $\alpha, P=$ 0.7498; GM-CSF $P=0 \cdot 0692$ ).

of T-cell activation. Calcitriol is a potent drug for the treatment of psoriasis. Thus, a possible mechanism of action of calcitriol as a drug is its action on T cells, i.e. the downregulation of local expansion and the production of one or more cytokines important in the pathophysiology of psoriasis.

\section{Acknowledgments}

This study was supported by a grant from the Solvay Duphar Pharmaceutical BV, Weesp, The Netherlands. The authors acknowledge Dr L.Kemény and Professor A.Dobozy for their helpful advice in preparing the manuscript.

\section{References}

1 Norman AW, Roth J, Orci L. The vitamin D endocrine system: steroid metabolism, hormone receptor, and biological response (calcium binding proteins). Endocr Rev 1982; 3: 331-66.
2 Hausler MR, McCain TA. Basic and clinical concepts related to vitamin D metabolism and action. N Engl J Med 1977; 297: 97483.

3 Holick MF, Smith E, Pincus S. Skin as the site of vitamin D synthesis and target tissue for 1,25-dihydroxyvitamin $\mathrm{D}_{3}$. Arch Dermatol 1987; 123: 1677-83a.

4 Smith EL, Walworth NC, Holick MF. Effect of $1 \alpha, 25$-dihydroxyvitamin $\mathrm{D}_{3}$ on the morphologic and biochemical differentiation of cultured human epidermal keratinocytes grown in serum-free conditions. J Invest Dermatol 1986; 86: 709-14.

5 Adams JS, Gacad MA. Characterization of 1-alpha hydroxylation of vitamin $\mathrm{D}_{3}$ sterols by alveolar macrophages from patients with sarcoidosis. J Exp Med 1985; 161: 755-65.

6 Bhalla AK, Amento EP, Krane SM. Differential effects of 1,25dihydroxyvitamin $\mathrm{D}_{3}$ on human lymphocytes and monocyte/ macrophages: inhibition of interleukin-2 and augmentation of interleukin-1 production. Cell Immunol 1986; 98: 311-22.

7 Rigby WFC, Stacy T, Fanger MW. Inhibition of T lymphocyte mitogenesis by 1,25-dihydroxyvitamin $\mathrm{D}_{3}$ (calcitriol). J Clin Invest 1984; 74: 1451-55.

8 Rigby WSC, Denome S, Fanger MW. Regulation of lymphokine production and human $\mathrm{T}$ lymphocyte activation by 1,25-dihydroxyvitamin $\mathrm{D}_{3}$. J Clin Invest 1987; 79: 1659-64.

9 Kragballe K. Vitamin $\mathrm{D}_{3}$ and skin diseases. Arch Dermatol 1992; 284 (Suppl.): S30-6.

10 Holick MF. Active vitamin D compounds and analogues: a new therapeutic era for dermatology in the 21st century. Mayo Clin Proc 1993; 68: 925-7.

11 Kemény L, Michel G, Dobozy A, Ruzicka T. Cytokine system as potential target for antipsoriatic therapy. Exp Dermatol 1994; 3: $1-8$.

12 Wong RL, Winslow CM, Cooper KD. The mechanisms of action of cyclosporin A in the treatment of psoriasis. Immunol Today 1993; 14: $69-74$

13 Uyemura K, Yamamura M, Fivenson DF et al. The cytokine network in lesional and lesion-free psoriatic skin is characterized by a T-helper type 1 cell-mediated response. J Invest Dermatol 1993; 101: 701-5.

14 Schlaak JF, Buslau M, Jochum W et al. T cells involved in psoriasis vulgaris belong to the Th1 subset. J Invest Dermatol 1994; 102: $145-9$.

15 Vollmer S, Mensen A, Trommler P et al. T lymphocytes derived from skin lesions of patients with psoriasis vulgaris express a novel cytokine pattern that is distinct from that of $\mathrm{T}$ helper type 1 and $\mathrm{T}$ helper type 2 cells. Eur J Immunol 1994; 24: 2377-82.

16 Barna M, Snijdewint FGM, van der Heijden FL et al. Characterization of lesional psoriatic skin T lymphocyte clones. Acta Derm Venereol (Stockh) 1994; Suppl. 186: 9-11.

17 Muller K, Odum M, Bendtzen K. 1,25-dihydroxyvitamin $\mathrm{D}_{3}$ selectively reduces interleukin-2 levels and proliferation of human $\mathrm{T}$ cell lines in vitro. Immunol Lett 1993; 35: 177-82.

18 Lemire JM, Archer DC, Beck L, Spiegelberg HL. Immunosuppressive actions of 1,25-dihydroxyvitamin $\mathrm{D}_{3}$ : preferential inhibition of Th1 functions (Review). J Nutrit 1995; 125: 1704S-8S.

19 van der Heijden FL, Wierenga EA, Bos JD, Kapsenberg ML. High frequency of IL-4-producing $\mathrm{CD}^{+}$allergen-specific T lymphocytes in atopic dermatitis lesional skin. J Invest Dermatol 1991; 97: 38994.

20 van der Pouw Kraan TM, van Kooten C, Rensink I, Aarden LA. Interleukin (IL)-4 production by human T cells: differential regulation of IL-4 vs. IL-2 production. Eur J Immunol 1992; 22: $1237-41$. 
21 van der Meide PH, Dubbeld M, Schellekens H. Monoclonal antibodies to human immune interferon and their use in a sensitive solid-phase ELISA. J Immunol Methods 1985; 79: 293305.

22 Gillis S, Ferm W, Ou W, Smith KA. T cell growth factor: parameters of production and a quantitative microassay for activity. J Immunol 1978; 120: 2027-32.

23 Fattah D, Quint DJ, Proudfoot A et al. In vitro and in vivo studies with purified recombinant human interleukin-5. Cytokine 1990; 2: $112-21$.

24 Ruff MR, Gifford GE. Rabbit tumor necrosis factor: mechanisms of action. Infect Immun 1981; 31: 380-5.

25 Provvedini DM, Tsoukas CD, Deftos LJ, Manolagas SC. 1,25dihydroxyvitamin $\mathrm{D}_{3}$ receptors on human leucocytes. Science 1983; 221: 1181-3.

26 Matsumoto K, Azuma Y, Kiyoki M et al. Involvement of endogenously produced 1,25-dihydroxyvitamin D-3 in the growth and differentiation of human keratinocytes. Biochim Biophys Acta 1991; 1092: 311-18.

27 Baadsgaard O. Potential mechanisms of action of vitamin D and analogues in psoriasis. Acta Derm Venereol (Stockh) 1994; Suppl. 186: 43 .

28 Danielsson C, Schräder M, Carlberg C. A display of vitamin D responsive genes. In: Abstract Book of Vitamin D: Actions and Applications in Dermatology, ESDR Clinically Oriented Symposium, Aarhus, 1995; 39.

29 Tsoukas CD, Watry D, Escobar SS et al. Inhibition of interleukin-1 production by 1,25-dihydroxyvitamin $\mathrm{D}_{3}$. J Clin Endocrinol Metab 1989; 69: 127-33.

30 Zhang, JZ, Maruyama K, Ono I, Iwatsuki K, Kaneko F. Regulatory effects of 1,25-dihydroxyvitamin $\mathrm{D}_{3}$ and a novel vitamin $\mathrm{D}_{3}$ analogue MC903 on secretion of interleukin-1alpha (IL- $1 \alpha$ ) an IL-8 by normal human keratinocytes and a human squamous cell carcinoma cell line (HSC-1). J Dermatol Sci 1994; 7: 24-31. 